\title{
Understanding barriers to energy-efficiency renovations of multifamily dwellings
}

\author{
Jenny Palm $\mathbb{D}$ - Katharina Reindl
}

Received: 21 August 2016 / Accepted: 13 July 2017 / Published online: 26 July 2017

(C) The Author(s) 2017. This article is an open access publication

\begin{abstract}
We have studied how energy efficiency is discussed by professionals during renovation of multifamily dwellings, in order to capture how barriers in relation to energy measures are appearing, disappearing and transformed during the process. We did participatory observations of renovation meetings, conducted interviews with the involved professionals and studied-related documents. Our intentions have not been to assess decisions made, but to follow the process to gain a different understanding of how barriers can be understood during renovations. We can conclude that the renovation process is based on a complex series of contractural relationships, where assymetric information and lack of common goals contribute to split incentives. The results also show that the housing company's internal organisation becomes a barrier where assymetric information and split incentives also became an in-house barrier. The decisions were often based on bounded rationality where calculations were surprisingly absent in meetings and during discussions on energy measures.
\end{abstract}

J. Palm $(\bowtie) \cdot$ K. Reindl

Department of Thematic Studies - Technology and Social Change, Linköping University, 58183 Linköping, Sweden

e-mail: jenny.palm@liu.se

e-mail: Jenny.palm@iiiee.lu.se

K. Reindl

e-mail: katharina.reindl@liu.se

J. Palm

International Institute for Industrial Environmental Economics (IIIEE), Lund University, Box 196, SE-221 00 Lund, Sweden
Keywords Energy efficiency · Renovation · Barriers · Buildings $\cdot$ Housing sector

\section{Introduction}

In its 20-20-20 strategy, the European Commission (EC) has estimated the technical energysaving potential of various sectors as $25 \%$ in manufacturing, $30 \%$ in commercial buildings and $26 \%$ in private households. The Swedish national strategy for the energy-efficiency renovation of buildings (a response to the EU's Energy Efficiency Directive) states that $75 \%$ of existing buildings will need comprehensive energyefficiency renovation measures by 2050 , i.e. $1,875,000$ apartments will need renovation (Swedish National Board of Housing Building and Planning and Swedish Energy Agency 2013). The escalating need for renovation of these buildings gives a window of opportunity to improve energy efficiency and approach international and national energy and climate goals.

However, both policy documents and the academic literature state that cost-effective energy measures are not always implemented. This discrepancy between optimal and actual implementation is referred to as the energy-efficiency gap or the energy paradox (see e.g. Blumstein et al. 1980; Hirst and Brown 1990; Gruber and Brand 1991; Stern 1992; Decanio 1998; Jaffe and Stavins 1994; Sanstad and Howarth 1994; Weber 1997; Sorrell 
2004; De Groot et al. 2001; Schleich and Gruber 2008; Backlund et al. 2012).

This energy paradox can be explained by the existence of barriers to energy efficiency, defined as postulated mechanisms that inhibit investments in technologies that are both energy efficient and economically sound (Sorrell 2004). Such barriers explain the reluctance to adopt cost-effective energy-efficiency measures derived from mainstream economics, organizational economics and organizational and behavioural theories. There are also institutional or structural barriers to energy efficiency that do not directly affect this "gap", although they do affect overall energy efficiency (Thollander et al. 2010).

Energy-efficiency barriers have been categorized in various ways. Sorrell et al. (2000) distinguish three main categories of barriers stemming from market failures, organizational failures and nonfailures, while Weber (1997) classifies the barriers as institutional, economic, organizational and behavioural. Hirst and Brown (1990) divide these barriers into two broad categories: structural and behavioural. The classification of barriers is not unambiguous, as a single type of real-world phenomenon may be explained by several theoretically derived barriers (Weber 1997; Palm and Thollander 2010; Leurent et al. 2017). The actual potential level of energy efficiency depends on which theoretical view is applied, which is why, for example, technological and economical potential might differ (Jaffe and Stavins 1994; Thollander and Palm 2013). Thollander et al. (2010) usefully treat energy-efficiency barriers as a dominant analytical framework for understanding the energy-efficiency gap. However, it is important to take a critical view of "barrier theory" and be aware of its limitations and possible development paths (Shove 2010; Palm and Thollander 2010; Janda 2011). Defining and redefining identified energyefficiency barriers are important in order to challenge existing solutions and develop new, creative ways of approaching companies and other actors. Not least, it is important to pay greater attention to social practices in companies and existing decision-making procedures (Palm 2009).

In this article, we follow how energy-efficiency measures are discussed in renovation projects in a municipal housing company in Sweden. Using observations and interviews, we investigate what different barriers appears, disappears and transform during the renovation process, and what we can learn about barriers by following the discussion about one suggested measurement more in-depth.

There are primarily three different tenure types in the Swedish multifamily building stock: municipality owned rental apartments, privately owned apartments and residential owned apartments. We have studied municipally owned rental apartments. The public housing sector is very large in Sweden compared to other countries in Europe and comprises as much as $68 \%$ of all dwellings (Meijer et al. 2009). Public housing companies are primarily owned by local municipalities. The principle behind the public housing is to provide access for everyone and without profit. In Sweden, there is no upper limit in income for those who rent an accommodation as is the case with those kinds of accommodations in the rest of Europe. The rent is set in negotiations and not by the housing market. The Swedish Union of Tenants is negotiating rents on behalf of their members, the tenants, on a yearly base, with the landlords.

We followed the planning and design phase of three renovation projects in a medium-sized Swedish city. We chose the planning and design phase because the decisions made in this phase determine the final results (Konstantinou and Knaack 2013). This company has both the goal of reducing the energy use throughout its housing stock by $25 \%$ of purchased energy by 2025 , compared with 2011 levels and the explicit goal of conducting energy-efficiency renovations.

\section{Identified barriers to energy efficiency in the building sector, construction industry and renovation projects}

This section discusses earlier research on barriers and buildings ending with a table showing common barriers identified. There are relatively few published studies on existing buildings (Afshari et al. 2016), thus the literature review was also extended to the building sector in general. For this reason, the studies have different focus areas, some emphasizing the renovation of individually owned homes, others emphasizing multifamily buildings, buildings in general, or low energy and nearly zero-energy building (nZEB) renovations. Studies identifying and discussing barriers in relation to the tenants are excluded in this article. We focused the review on 
Western countries in order to have similar conditions as in Sweden.

Technical and organisational barriers as well as barriers related to the construction industry can vary between different studies. Innovations and energy-efficient building solutions are often not used in the (Swedish) building sector as research on technological change in the building sector points to a lack of transformation pressure, an aversion to change or territorial thinking and path dependency (Persson and Grönkvist 2015) .

Other technical barriers can be found in different studies. Discrepancies between predicted and actual savings can also be observed. A renovation might lead to improved thermal comfort standards but fail to realize expected energy savings. This can be explained, for example, by the impact of thermal bridges, insulation gaps and occupant use of more heat after a renovation (Dowson et al. 2012). Poorly realized savings may also stem from increased heating use because of people's behaviour and thermal comfort take-back after a renovation and the installation of a new heating system (Dowson et al. 2012).

Sorrell (2003) states that energy-efficiency opportunities are also commonly missed by the oversizing of heating, ventilation and air-conditioning (HVAC) systems. Another barrier is the fragmentation of the construction industry, which involves many different actors and stakeholders working together in temporary coalitions. These diverse stakeholders with varied interests can in themselves constitute a barrier (Häkkinen and Belloni 2011; Lindkvist et al. 2014; Sorrell 2003). Construction projects can be described as temporary coalitions of firms working together through subcontracting (Sorrell 2003). This leads to complex and detailed contracts as well as to characteristically low-trust, adversarial relationships.

The lack of time that contractors and suppliers have to prepare bids combined with low profit margins and lack of trust can lead to inappropriately specified bids. One also observes a tendency to reuse bids from previous projects, with only slight modifications to fit the current contract, which can lead to outdated specifications and ignoring the specific client's needs (Sorrell 2003). Time is also another important factor as, for example, it might be easier or less time consuming to design a crude building instead of spending additional time and effort on new solutions, even though they may reduce capital and operating costs. This leads to a tendency to maintain current practices (Ahn et al. 2013; Sorrell 2003; Palm and Reindl 2016).

A lack of project integration can result from a lack of communication and mutual understanding among the involved professional disciplines. This poor integration is reinforced by the fact that the construction industry is fragmented, the dominant project form being subcontracting with new teams of designers, builders, and suppliers typically being used for each project. As a result of these conditions, coordination and learning are inhibited and there is no latitude to develop skilled and integrated teams (Sorrell 2003; Palm and Reindl 2016).

Lack of information about existing renovation measures can also constitute a barrier (Baek and Park 2012; Phillips 2012). Varying energyefficiency ambitions also have an impact. In a project, technical solutions and knowledge of possible measures need to go hand in hand with energy-efficiency goals (Lindkvist et al. 2014).

Financial difficulties constitute another commonly mentioned barrier to improving energy efficiency in dwellings (Ahn et al. 2013; Baek and Park 2012; Dowson et al. 2012; Häkkinen and Belloni 2011; Lindkvist et al. 2014; Serpell et al. 2013; Persson and Grönkvist 2015). Renovation costs are often very high, even in fairly new buildings (Baek and Park 2012). Energyefficiency goals are often secondary to economic considerations. In relation to rental properties lifecycle costs are typically not taken into consideration and energy-efficiency options are overlooked, even though the return rates would substantially exceed the capital costs. This initial cost-premium barrier causes developers and investors to hesitate to adopt sustainable practices in their investments (Lindkvist et al. 2014). Serpell et al. (2013) treat the need to introduce policy measures such as reduced corporate taxes if energy-efficiency and sustainability investments are to be made. In addition, a building's energy performance is viewed as less important than its investment value. Even if energy performance raises the asset value of a building, it is still not easy to show this increased value to possible buyers or renters/tenants (Baek and Park 2012).

The effects of improved energy efficiency are difficult to recognize, and even a successful energyefficiency measure can be cancelled out by increasing energy prices. Although the operating expenses of, for 
example, lighting or heating may be reduced by a renovation, the cost is usually high and the pay-back period might be long (Baek and Park 2012; Högberg 2011; Cooke et al. 2007).

Contractors are usually selected through competitive tendering and decisions are typically based on the lowest price. As a result, price competition is fierce and margins are low, both of which are conditions that encourage cost cutting to make the tender as thrifty as possible to maximize profits. Competitive tendering can be seen as a key reason for inefficiency in the construction industry. A building project process can be described as a series of sequential and separate operations uniting various temporarily joined people, such as individual designers, inspectors, and suppliers. These groups of people usually have no stake in or commitment to long-term project success (Sorrell 2003). These empirically found barriers are summarized in Table 1.

\section{Methodology}

The most common way to study barriers is to map their existence in a sector. Few studies have conducted qualitative in-depth analyses and followed barriers throughout a project (Thollander et al. 2010; Thollander and Palm 2013), which is what we do here in analysing three renovation processes. We conducted a case study in order to get a deeper understanding of the energyefficiency discourse in the company.

The three followed renovation projects take place within the same housing company. Thus, it is regarded as one case (the housing company), in which three renovations are conducted. This makes it possible and easier to discuss the role of the company strategies regarding energy efficiency and the renovation.

The municipal housing company is in a mediumsized Swedish town and rents out apartments, many of which are in multifamily dwellings. The three renovation objects for our study were built in the 1950s and 1960s and are located close to the city centre. The buildings were selected for renovation as they were having issues with ventilation, piping, or different types of damages. Table 2 gives a more detailed overview of the buildings.

The data collected include field notes from the participant observations, interview transcripts, and in addition, the researchers were granted full access to relevant
Table 1 Summary of most common identified barriers to energy efficiency in buildings in earlier research

\begin{tabular}{|c|c|c|}
\hline Category & Theoretical barriers & Comments \\
\hline \multirow[t]{3}{*}{$\begin{array}{l}\text { Organisation } \\
\text { of the } \\
\text { market }\end{array}$} & Fragmented market & $\begin{array}{l}\text { Fragmented industry and } \\
\text { temporary coalitions, } \\
\text { (Häkkinen and Belloni } \\
\text { 2011; Lindkvist et al. } \\
\text { 2014; Sorrell 2003), } \\
\text { issues with } \\
\text { subcontracting (Sorrell } \\
\text { 2003). Designers, } \\
\text { consultants and } \\
\text { subcontractors lack } \\
\text { long-term interest in a } \\
\text { building (Sorrell 2003) } \\
\text { Lack of project integration } \\
\text { and communication } \\
\text { between involved } \\
\text { actors (Sorrell 2003; } \\
\text { Palm and Reindl 2016) } \\
\text { Exhortations to consider } \\
\text { whole life costs are } \\
\text { weak (Sorrell 2003) }\end{array}$ \\
\hline & Split incentives & $\begin{array}{l}\text { Diverse stakeholders with } \\
\text { varied interests } \\
\text { (Häkkinen and Belloni } \\
\text { 2011; Lindkvist et al. } \\
\text { 2014; Sorrell 2003) } \\
\text { Building services } \\
\text { contractors have } \\
\text { incentives to oversize } \\
\text { equipment (Sorrell } \\
\text { 2003) }\end{array}$ \\
\hline & Lack of time & $\begin{array}{l}\text { Lack of time, reuse of bids } \\
\text { due to lack of time, and } \\
\text { no time for } \\
\text { brainstorming or } \\
\text { creativity, (Sorrell } \\
\text { 2003) and tendency to } \\
\text { maintain current } \\
\text { practices (Ahn et al. } \\
\text { 2013; Sorrell 2003; } \\
\text { Palm and Reindl 2016). } \\
\text { Less time consuming to } \\
\text { design a crude building } \\
\text { instead of spending } \\
\text { time on new solutions, } \\
\text { even (Ahn et al. 2013; } \\
\text { Sorrell 2003; Palm and } \\
\text { Reindl 2016). }\end{array}$ \\
\hline Information & Imperfect information & $\begin{array}{l}\text { Lack of information and } \\
\text { knowledge about } \\
\text { energy-efficient and } \\
\text { sustainable materials } \\
\text { and products (Baek and } \\
\text { Park 2012; Phillips } \\
\text { 2012), }\end{array}$ \\
\hline
\end{tabular}


Table 1 (continued)

\begin{tabular}{lc}
\hline Category & Theoretical barri \\
\hline $\begin{array}{c}\text { Behavioural } \\
\text { barriers }\end{array}$ & $\begin{array}{c}\text { Lack of sharing } \\
\text { objectives }\end{array}$
\end{tabular}

Other priorities

Bounded rationality

Technical

Financial

Inertia
Comments

Energy measures need to go hand in hand with goals (Lindkvist et al. 2014)

Even if measures reduce energy, it is high initial costs and long payback-prioritisation of competitive tendering with lowest price (Ahn et al. 2013; Baek and Park 2012; Dowson et al. 2012; Häkkinen and Belloni 2011; Lindkvist et al. 2014; Serpell et al. 2013; Persson and Grönkvist 2015)

Conservatism in the building industry; lack of transformation pressure, aversion to change, path dependency, territorial thinking (Persson and Grönkvist 2015)

Instead of being made based on, for example, perfect information and complete rationality, decisions are often made in constrained environments that result in limited, or bounded, decisions, i.e. nonoptimal from a fully rational point of view, i.e. rule of thumb is used (Sorrell 2003; Palm and Reindl 2016).

Discrepancies between predicted and actual savings, e.g. due to insulation gaps

(Dowson et al. 2012)

Building's energy performance is viewed as less important than its investment value (Baek and Park 2012; Serpell et al. 2013; Lindkvist et al. 2014)

High investment costs Initial cost premium, high and no LCC costs, long pay-off time, perspective
Table 1 (continued)

\begin{tabular}{|c|c|c|}
\hline Category & Theoretical barriers & Comments \\
\hline & & $\begin{array}{l}\text { perspective, and lack of } \\
\text { financial incentives } \\
\text { (Ahn et al. 2013; Baek } \\
\text { and Park 2012; Dowson } \\
\text { et al. 2012; Häkkinen } \\
\text { and Belloni 2011; } \\
\text { Lindkvist et al. 2014; } \\
\text { Serpell et al. 2013; } \\
\text { Persson and Grönkvist } \\
\text { 2015) }\end{array}$ \\
\hline & External risk & $\begin{array}{l}\text { Success of energy saving } \\
\text { depends on energy } \\
\text { price (Ahn et al. 2013; } \\
\text { Persson and Grönkvist } \\
\text { 2015; Sorrell 2003) }\end{array}$ \\
\hline
\end{tabular}

internal documents by the company. The data collection period was from November 2012 to October 2014.

In total, the researchers observed 18 planning and design meetings. Each project had six meetings. The general timeframe for the planning and design meetings was around 3 months, followed by the procurement process. Notes were taken on all meetings (Clark et al. 2009; Johnson and Turner 2003).

In total, 30 semi-structured interviews were conducted with all professionals involved in the planning and design phase for all three projects. This includes all the members of the project group for the planning and design phase ( 25 interviews) and all the members of the investment group (five interviews). The project group comprised both external consultants and internal employees. External consultants consisted of architects, fire consultants, construction consultants, HVAC consultants, building engineers, energy audit consultants, noise consultants, and an electricity controller. Internally, the housing company also has an HVAC and electricity function having the same role as the external one. In addition there was a project manager, area manager, rent negotiator, energy manager, real estate development manager and trainee. Three people were interviewed twice (two project managers and the real estate development manager) for further clarifications. Internally, the project group involved similar people, except for different project managers, area manager and trainees. Externally, one HVAC consultant and architect participated in two of the projects and the electricity consultant was the same on all three projects. 
Table 2 Characterization of the three renovation objects

\begin{tabular}{|c|c|c|c|}
\hline & Project 1 (RP1) & Project 2 (RP2) & Project 3 (RP3) \\
\hline Built & 1961 & early $1950 \mathrm{~s}$ & 1961 (partly renovated in 1985) \\
\hline Number of apartments & 12 & 33 & 32 \\
\hline Floors & 4 & 3 & 4 \\
\hline $\begin{array}{l}\text { Energy consumption of } \\
\text { the buildings }\end{array}$ & $153 \mathrm{kWh} \mathrm{m}^{-2} \mathrm{y}^{-1}$ & $141 \mathrm{kWh} \mathrm{m}^{-2} \mathrm{y}^{-1}$ & $154 \mathrm{kWh} \mathrm{m}^{-2} \mathrm{y}^{-1}$ \\
\hline $\begin{array}{l}\text { Energy-related } \\
\text { measurements } \\
\text { included in the } \\
\text { tender document }\end{array}$ & $\begin{array}{l}\text { District heating was installed and will be kept } \\
\text { HRV ventilation } \\
\text { Attic (floor)/loft supplementary insulation } \\
\text { with } 300 \mathrm{~mm} \text { of mineral wool. } \\
3 \text { glazing and fitted with interior blinds. U- } \\
\text { value: } 1.1 \mathrm{~W} / \mathrm{m}^{2}, \mathrm{~K} \text {. Windows with } \\
\text { balcony, } \mathrm{U} \text {-values: } 0.9 \text { and } 1.1 \mathrm{~W} / \mathrm{m}^{2} \mathrm{~K} \\
\text { Exterior doors and entrances. Insulation } \\
\text { values, Umax }=0.8 \text { and } 1.1 \mathrm{~W} / \mathrm{m}^{2}{ }^{\circ} \mathrm{C} \\
\text { Exterior walls supplementary insulation with } \\
100 \mathrm{~mm} \text { mineral wool } \\
\text { Appliances, energy class A++ }\end{array}$ & $\begin{array}{l}\text { (This document } \\
\text { included no } \\
\text { figures) } \\
\text { Insulation of facades } \\
\text { and attics } \\
\text { Replacing windows } \\
\text { HRV ventilation } \\
\text { change as stoves }\end{array}$ & $\begin{array}{l}\text { District heating installed and will be kept } \\
\text { Building 1: mechanical exhaust air system is } \\
\text { kept } \\
\text { Building } 2 \text { : HRV ventilation } \\
\text { Attic (floor)/loft additional insulation with } \\
400 \mathrm{~mm} \text { blowing wool } \\
\text { 3-glazing and fitted with interior blinds. U- } \\
\text { value: } 1.1 \mathrm{~W} / \mathrm{m}^{2} \mathrm{~K} \text {. Windows facing } \\
\text { balconies, } \mathrm{U} \text {-values: } 0.9 \text { and } 1.1 \mathrm{~W} / \mathrm{m}^{2} \mathrm{~K} \\
\text { Exterior doors and entrances. U-value better } \\
\text { than } 1.1 \mathrm{~W} / \mathrm{m}^{2} \mathrm{~K} \\
\text { Exterior walls with additional insulation of } \\
100 \mathrm{~mm} \text { mineral wool } \\
\text { Appliances energy class A+ }\end{array}$ \\
\hline
\end{tabular}

An interview guide was used to determine the overall structure of interview topics. In addition, each interview included specific questions arising from each observed process and tailored to specific roles and jobs (Kvale and Brinkmann 2009). The interview guide for the project group comprised questions on their background and current job, how they thought the renovation process was going, if there were differences to previous projects, what is important to achieve with a renovation and difficulties and obstacles with a renovation. Interviews for the project group were conducted about halfway through each planning and design phase of each renovation project. The interviews with the investment group were conducted towards the end of the planning and design phase. Each interview was recorded and transcribed. The material was structured and thematic codes were created.

The interviewees' perceptions were compared with other interviewees and with the documents and our observation notes. The validity of this study is in this way supported by data triangulation, i.e. the use of multiple data sources and respondents (Maxwell 2005).

\section{Results: barriers in renovation projects}

Earlier studies have demonstrated that barriers are often cited in explaining why renovations do not include energy-efficiency measures. We became interested to see how different barriers appeared and disappeared and also transformed during the process. In the following, we will discuss two quite specific situations when energy measures were discussed and where the decision on whether to implement a measurement or not changed during the process. But we start by giving a more general overview of the renovation processes studied.

General overview of the renovation process in the studied housing company

We will first describe the renovation process focussing on the second phase, the planning and design phase, in which the content of the tender document is determined (Fig. 1).

The planning and design phase in our case studies was conducted by the property developer jointly with its consultants. The consultants hired in this phase were chosen from a list of consultants contracted through public procurement for 3 years, a new procurement being conducted every 3 years. In our cases, the planning and design phase can be seen as an action planning phase in which goals are broken down into sub-goals and details are clarified or simply deleted from the agenda. This phase ends with a tender document. 
Fig. 1 Overview of the renovation process in the studied housing company

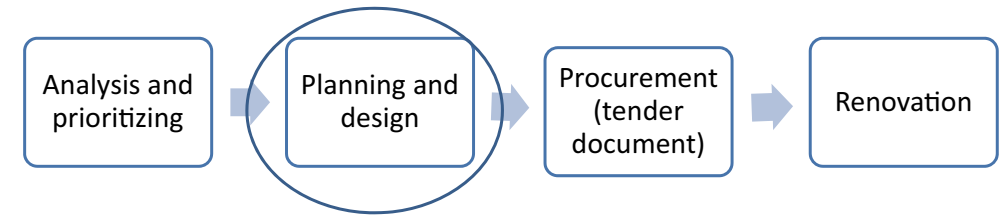

The project manager and the consultants initiate the planning and design phase, in which specific renovation measures are discussed and decisions are made about what to include in the renovation. When the project manager has a first draft of the tender document incorporating the suggested measures, this is presented to the investment group. This group consists of the public housing company's management team, which comprises the CEO, real estate development manager, business unit director, controller, and real estate manager. It is the group's task to make a preliminary decision on the project orientation. In preparation for the final investment decision, the investment group evaluates the selected measures and ideas and decides whether they seem financially feasible. The final investment decision comes later in the process, and the preliminary orientation decision is intended to make the investment decision process smoother so that little will need to be changed in the end. However, a project can go back and forth between planning and design meetings and the investment group, and orientation decisions can be made several times during the planning and design phase. The final investment decision determines what the tender document will ultimately look like (housing company internal process document; interview, e.g. Internal 4, 5, 6).

An economic framing of the renovations

More or less, all the interviewees meant that it was "money" that decided what energy-efficient measures to implement. No LCC perspective was applied and in the end energy-efficient measures were often regarded too expensive.

So first you want to do it, then it will cost and then you do not do it. Where it might, if one factored in 30 years, the cost may have payed off [...]. (External consultant 1 )

The economic restrictions could also be seen during the project meetings since the project group members themselves adapt to an economic argumentation. Even the standard energy measurements, which are commonly used by the housing company, were not always implemented due to initial cost premium and lack of LCC perspective. Measures were discussed in relation to whether they had a payoff time of more or less than 6 years. If the payoff time was presented as less than 6 years, they were implemented. During the project meeting, such measures were the installation of energyefficient appliances in the apartments and the laundry room and also the installation of a heat recovery ventilation (observation notes, e.g. 17 Jan 2013; 14 Feb 2013; 15 Jan 2014).

The method for calculating the pay-off time of energy-efficiency measures was done according to an own defined formula. The housing company representatives reflected on the fact that they did not yet really know how to calculate the pay-off time of energy-efficiency measures. They stated that the formula they used was too pessimistic compared with others, with the result that energyefficiency measures were easily rejected.

Yes, we are looking at different calculations ... we have said that we will implement energy measures with a maximum pay-off of six years. ... Then we opt for them without an investment decision. But it is difficult in the case of changing windows ... insulating façades ... and we have also noticed that other companies get a better pay-off than we do. We have concluded that they probably just consider the additional costs, for example, of adding a third pane to a window, and then they got a different pay-off time ... so we are looking into that now. We feel that we calculate this too pessimistically. (Investment group 3)

Energy calculations were surprisingly absent during the meeting and had low impact on the decisions. In the projects, an HVAC or energy consultant was assigned to do energy calculations, but the calculations were not presented at the meetings and it was unclear how and to what 
extent these calculations actually were done and if so how they were used. No energy calculation was made for any of the renovation projects based on data or statistics of how much energy the buildings were consuming before the renovation, nor was a goal set regarding how much energy saving should be achieved with the renovation. The figures used were based on past experience and 'standard buildings' (interview project leader 1). Calculations were said to be made, but it was not easy to get hold of them in all projects and in one project no one could find them or knew who had them. The lack of calculations contributed to a process characterized by bounded rationality where decisions based on rule of thumbs were common.

Next, we will look into a conflict that appears around LED lamps and if to install them or not. In this conflict, several barriers appear related to contractural relationship, lack of common goals, assymetric information and split incentives.

The meaning of electricity efficiency measures, the case of LED lamps

Within the housing company, there was a common view that as many energy-efficiency measures as possible should be implemented within reasonable economic limits. We could however observe that there was lack of intention to save electricity. The common view was electricity is not an issue worth spending time on. The electricity consultant said:

I have given the electricity manager at [name of the housing company] a list of measures that would save electricity and have short pay-off times, but they have not been implemented. ... There are a lot of measures to implement, but the problem is that electricity [consumption] is too small in relation to the total. So you don't save $25 \%$ in total if you reduce the electricity consumption by $50 \%$. To save $25 \%$ you need to include HVAC. (External 2)

One of the HVAC consultant said:

They don't care so much about electricity - there is so little ... In the big picture, it costs nothing...
Even if you save $50 \%$, it is like a drop in the ocean. (External 3)

In general, one can say that there was a common understanding that the measures making the greatest difference regarding energy efficiency were related to ventilation, window replacement, laundry rooms, heating systems and insulation as well as reduced air leakage.

However, in one of the projects LED lamps became ground for a rather prolonged conflict. The question concerned if to install LED lamps in the apartments or not. The discussion took place between the area manager, the project leader and the external electricity consultant. The area manager was a proponent of LED lamps because he meant they are energy efficient, will be widely used and popular in the future and they were asked for by the tenants. The external electricity consultant strongly argued against LED lamps and said amongst others:

Yes, I have the opinion that it is lobbying, it is too much trust in this. Let the others make the mistake, we do not need to do them. [...] The energy saving is not so great as people think, there is less energy than a low-energy lamp, but it is not that amazingly much lower [...]. (External 2)

During the meetings of the project group no obvious decision was taken. The discussions went back and forth. We asked the project leader and area manager what has happened in the LED discussion. The first impression, after talking to the project leader, was that it was decided not to use LED lamps. The reason why LED lamps would not be selected was that the technology was regarded as being too immature and therefore the risk would be too big:

So we want to wait a bit more so that we do not do any mistakes that it becomes more expensive in the end and we have to exchange the fixtures... (Internal 6).

About 1 month later, we interviewed the area manager. Then it seemed like the area manager had put pressure on other professionals in the project group and LED lamps were selected after all.

I don't think you can just see to the cost, but you must also have an attitude about what we are doing and sometimes it must simply be allowed 
to cost a little more. [...] And I think the relationship between us and the consultants are wrong. I had to have a discussion first with the project leader, who referred me to the ... person internally responsible for electricity, who has expertise in this, who then referred me to the real estate development manager, who said that this is a strategic question and it is uncertain who takes the decisions. And then I became really angry. You have to take responsibility for the decisions and then you have to know who decides and say what our position is in this. But then we agreed that LED lamps would be implemented. (Internal 7)

In this case, several barriers appear. The renovation process is based on a complex series of contractual relationships, in which asymmetric information and different goals contribute to split incentives in the project group. In this case, it was interesting to see that it was the external consultant pleading against LED because it was an unproven technology, which was expensive with a high risk of failure. The internal area manager on the other side meant it was an energy-efficient measure that should be implemented even if the cost became slightly higher. There were no calculations, scientific studies or similar presented and bounded rationality characterized the conflict. Other barriers were inertia and lack of a common goal to evaluate the suggested measure against.

The next example concerns the heating system.

Keeping or changing the heating system

The share of multifamily dwellings heated by district heating is large in Sweden compared to EU. In apartment buildings, district heating is the dominant source of heat with around 64\% (Meijer et al. 2009). All buildings in the three renovation projects were attached to district heating. District heating is also used for water heating. Both heating and water-heating is included in the rent, while electricity has individually metering and charging. This made heating a much bigger cost than electricity for the housing company.

This example is how the energy system was discussed in one of the renovation projects. In this case, the orientation decision process was protracted and the project was discussed several times by the investment group when meeting to make decisions.

During the project meetings, it was soon clear that the heating system needed replacement. The main reason was purely technical. Such heating systems were said by the consultants to have a life span about 30 years, but the system in renovation project 1 was over 50 years old and was described in the meetings as a "ticking time bomb" that could break down any time. Of course, no one could know exactly when the system would break down, but it would likely do so within the next few years. If that happened, then the whole renovation would essentially need to be redone, which would be costly and time consuming. The project group agreed that the best recommendation for the investment group was to change the heating system.

The project presented to the investment group included replacing the heating system. The investment group decided, however, not to replace the system because it was deemed an unnecessary cost. The extra cost of replacing the system was estimated at approximately EUR 22,000. The whole renovation project was estimated to cost approximately EUR 1,200,000, so the cost of the heating system replacement, though substantial, was not a huge part of the total cost.

When this first decision was presented to the project group many members, both internal and external, became quite upset. One consultant later explained in the interview why he had become so upset:

But now we are doing a total renovation. And then I asked what we should do with the heating system. It is 40 to 50 years old. Will we replace it or should we keep it? The project manager said that we should replace it. But that costs, I said. No, there is nothing to discuss, he said. ... Everyone, except those in charge, agreed with this. I mean, they don't know what they are doing. They don't understand the decisions they make. They look only at the money, the finances, not the consequences. (External consultant 3)

Internal employees from the housing company were also critical of the decision made by the investment group:

Internal 4: No, I don't like that we didn't replace the heating system. It was a pity, I think. They didn't understand that they would save ... it will be almost as expensive anyway and it will complicate the process to keep the old pipes.

Interviewer: But why could you replace the system in project 2 but not in this project? 
Internal 4: No, I cannot answer that.

Interviewer: Because it would be much more expensive?

Internal 4: No, I mean ... it is ... but ... I think that it will be much more expensive [not to replace the system]. No, I think that it was a wrong decision. (Internal 4)

Another internal participant believed that it was necessary to replace the system from a technical standpoint:

Because, if you start screwing and banging, then the risk is that it will start to leak. No, this is a decision made at another level, where the money rules. (Internal 5)

One external consultant felt that the decision from the investment group was so unacceptable that he decided to call a member of the investment group to try to convince him that the investment group needed to reconsider the decision. The representative of the investment group refused to discuss the matter with the consultant, and instead referred him back to the project manager. This consultant saw it as a matter of professional pride to attempt to have the decision changed:

No, I don't want to stand there with my head hanging when everything is finished and it starts to leak and everyone in town is talking. The industry is not that big ... Who is the consultant? Yes, it is [consultant's name] and he didn't say anything. (External consultant 3)

One member of the investment group explained why they were reluctant to replace the heating system:

From the beginning we thought that we should change [the system] and then I was actually the one who said: Why should we replace the heating system, no one does that? If you owned the building you would never change the system; why should we do that just because we are [the name of the housing company], why? ... No other private company would replace it. Answer that. (Investment group 2)
Another member of the investment group reflected on the problems connected to the fact that the investment group does not follow the planning and design phase and does not know how various issues have been discussed before being presented to them:

Sometimes I think ... we undertake quite thorough investigations, we have consultants, we think internally, we have experts and everything is going on for quite a long time, and then you end by approaching the investment group that has not participated in this journey at all. And they say, "No, this is not possible, it is crazy". The system must stay, and then we try to say that we have discussed this, but okay, we take it another turn then. (Internal 3)

Discussion of the heating system continued for several months before the investment group finally discussed the issue again. By then, informal contacts had been made. The calculations and the arguments were still the same the second time, but the results were the opposite. The new decision was now to replace the system. The second time the investment group accepted the arguments put forward that it was too risky not to change the system. By just studying the material presented to the investment group nothing had really changed, but the informal contacts had resulted in a change of mind by the members of the investment group. To the investment group this did not seem to be a major reversal or indicate a loss of prestige:

With energy saving and everything, sometimes you need to step aside and ... I mean, we could keep the old heating system even though we know that it is not good to keep pipes that are 40 years old, but if there is no money, then we need to take a chance. But sometimes, of course, you need to back off. (Investment group 4)

However, one person in the investment group, even after the decision was made to replace the heating system, was reluctant to acknowledge whether that was the best decision. He was quite convinced a heating system can last well over 50 years without problems, and questioned that the replacement was an investment at all. 
The heating system, which is a great thing to discuss. Why should we replace the heating system? They say yes, it is embedded pipes and there is a great risk that there will be damage. But... it's just a pure cost, it is a cost that is taken from year one ... that is no investment... Normally, you do not replace it, it will last one hundred years. (Investment group 2)

The decision to replace or not to replace the heating system is an example of how economic arguments change during the process and are dependent on how they are defined, as costs or investments, and if they are discussed in a long or short-term perspective. The case also exemplifies an organisational barrier within the housing company. It seems as the idea of having an investment group that is not deeply involved in project planning and yet makes the final decision on renovation implementation can lead to a barrier in itself. The investment group lack knowledge of both technical preconditions and of how the project group reasons about a problem such as the heating system. The investment decision is made in isolation from the work in the project group, which creates an information gap and problems with adverse selection where the project group knows more about the energy performance of a technology than the investment group does, the investment group select measurements on the sole basis of price.

\section{Conclusions}

We have followed two discussions around energy measures discussed by professionals during renovation meetings, in order to understand which barriers that can be identified and how they appear, disappear and transform during these discussions. Our intention has not been to assess the decisions or judge whether these were good or bad decisions. The intention was to follow the process to understand the professionals' perceptions to shed different light on how barriers appears, disappears and are transformed during the process of the planning and design.

Energy-efficiency renovation is not a linear process, as the design and goals change throughout the process. Barriers must be seen holistically with the awareness that a barrier can change in importance and meaning relative to how a renovation process is developing. A barrier exists in a specific social context in which actors constantly interact and negotiate what measures to adopt and to reject. Decisions are not made in a vacuum but in a context in which the actors are influenced by regulative rules, normative rules, cognitive routines and belief systems. That is also why for example the replacement of a heating system can first be seen as too expensive and then later in the process be regarded as financially acceptable. And this happens without any new calculations being presented. We saw from their comments that the members of the project group did not spend time recalculating the investment cost of a new heating system, but rather put their energy into communicating with and convincing the investment group to change their decision.

In the arguments about if to install LED lamps the framing of the problem changed during the process. It went from that LED lamps were a too immature technology to that it should be implemented to meet the tenants' requests. In general, the lack of further investigations in relation to what measures to include and exclude in the renovation, contributed to that the decision process were characterized by bounded rationality.

Energy-efficient renovations are multi-faceted and should be approached accordingly. In this project, we used a process approach and followed renovation projects over time. This gives a complementary view to earlier studies where existing barriers are studied at one occasion, when the questionnaires are answered or the interview conducted.

Barrier theory helps identify and give an overview of the possible obstacles to energy-efficiency renovations. But different barriers appear in different phases and some disappear or transform to drivers in the process. This is why, it is important to do in-depth studies and follow a process as complements to surveys. In this case, we could recognise several of earlier identified barriers in the construction sector, such as contractural relationship, lack of common goals, assymetric information, split incentives and energy performance less valued than investments costs. In addition to these, we found that internal organisational barriers became important explanations to understand why or why not energy-efficient measures become implemented. The division with a project group and an investment group creates adverse selection and an information gap. Within the project group, there was also a lack of common goals on electricity and no one within the housing company was assigned to identify opportunities when it comes to electricity. 
Acknowledgements This work was supported by FORMAS and IQS Samhällsbyggnad under grant number 2012-246. The authors would also like to acknowledge the valuable comments from the anonymous reviewers.

\section{Compliance with ethical standards}

Conflict of interest The authors declare that they have no conflict of interest.

Open Access This article is distributed under the terms of the Creative Commons Attribution 4.0 International License (http:// creativecommons.org/licenses/by/4.0/), which permits unrestricted use, distribution, and reproduction in any medium, provided you give appropriate credit to the original author(s) and the source, provide a link to the Creative Commons license, and indicate if changes were made.

\section{References}

Afshari, H., Issa, M. H., \& Radwan, A. (2016). Using failure mode and effects analysis to evaluate barriers to the greening of existing buildings using the Leadership in Energy and Environmental Design rating system. Journal of Cleaner Production, 127, 195-203.

Ahn, Y. H., Pearce, A. R., Wang, Y., \& Wang, G. (2013). Drivers and barriers of sustainable design and construction: The perception of green building experience. International Journal of Sustainable Building Technology and Urban Development, 4(1), 35-45.

Backlund, S., Thollander, P., Palm, J., \& Ottosson, M. (2012). Extending the energy efficiency gap. Energy Policy, 51, 392396. doi:10.1016/j.enpol.2012.08.042.

Baek, C., \& Park, S. (2012). Policy measures to overcome barriers to energy renovation of existing buildings. Renewable and Sustainable Energy Reviews, 16(6), 3939-3947. doi:10.1016 j.rser.2012.03.046.

Blumstein, C., Krieg, B., Schipper, L., \& York, C. (1980). Overcoming social and institutional barriers to energy conservation. Energy, 5(4), 355-371. doi:10.1016/0360-5442(80)90036-5.

Clark, A., Holland, C., Katz, J., \& Peace, S. (2009). Learning to see: lessons from a participatory observation research project in public spaces. International Journal of Social Research Methodology, 12(4), 345-360.

Cooke, R., Cripps, A., Irwin, A., \& Kolokotroni, M. (2007). Alternative energy technologies in buildings: stakeholder perceptions. Renewable Energy, 32(14), 2320-2333. doi:10.1016/j.renene.2006.12.004.

De Groot, H. L. F., Verhoef, E. T., \& Nijkamp, P. (2001). Energy saving by firms: decision-making, barriers and policies. Energy Economics, 23(6), 717-740. doi:10.1016/S01409883(01)00083-4.

Decanio, S. J. (1998). The efficiency paradox: Bureaucratic and organizational barriers to profitable energy-saving investments. Energy Policy, 26(5), 441-454. doi:10.1016/S03014215(97)00152-3.
Dowson, M., Poole, A., Harrison, D., \& Susman, G. (2012). Domestic UK retrofit challenge: barriers, incentives and current performance leading into the Green Deal. Energy Policy, 50, 294-305. doi:10.1016/j.enpol.2012.07.019.

Gruber, E., \& Brand, M. (1991). Promoting energy conservation in small and medium-sized companies. Energy Policy, 19(3), 279-287. doi:10.1016/0301-4215(91)90152-E.

Häkkinen, T., \& Belloni, K. (2011). Barriers and drivers for sustainable building. [article]. Building Research and Information, 39(3), 239-255. doi:10.1080 /09613218.2011.561948.

Hirst, E., \& Brown, M. (1990). Closing the efficiency gap: barriers to the efficient use of energy. Resources, Conservation and Recycling, 3(4), 267-281. doi:10.1016/0921-3449(90 )90023-W.

Högberg, L. (2011). Incentives for energy efficiency measures in post-war multi-family dwellings. Licentiate thesis, KTH Royal Institute of Technology, Stockholm.

Jaffe, A. B., \& Stavins, R. N. (1994). The energy-efficiency gap what does it mean? [article]. Energy Policy, 22(10), 804-810. doi:10.1016/0301-4215(94)90138-4.

Janda, K. B. (2011). Buildings don't use energy: people do. Architectural Science Review, 54(1), 15-22.

Johnson, B., \& Turner, L. A. (2003). Data collection strategies in mixed methods research. In A. Tashakkori, \& C. Teddlie (Eds.), Handbook of mixed methods in social and behavioral research (pp. 297-319). Thousand Oaks, Calif: SAGE Publications.

Konstantinou, T., \& Knaack, U. (2013). An approach to integrate energy efficiency upgrade into refurbishment design process, applied in two case-study buildings in Northern European climate. Energy and Buildings, 59, 301-309. doi:10.1016/j. enbuild.2012.12.023.

Kvale, S., \& Brinkmann, S. (2009). InterViews: learning the craft of qualitative research interviewing. Los Angeles: Sage Publications.

Leurent, M., Jasserand, F., Locatelli, G., Palm, J., Rämä, M., \& Trianni, A. (2017). Driving forces and obstacles to nuclear cogeneration in Europe: lessons learnt from Finland. Energy Policy, 107, 138-150.

Lindkvist, C., Karlsson, A., Sørnes, K., \& Wyckmans, A. (2014). Barriers and challenges in nZEB Projects in Sweden and Norway. Energy Procedia, 58, 199-206.

Maxwell, J. A. (2005). Qualitative research design: an interactive approach (applied social research methods series, 990497898-0 ; 41). Thousand Oaks: Sage Publications.

Meijer, F., Itard, L., \& Sunikka-Blank, M. (2009). Comparing European residential building stocks: Performance, renovation and policy opportunities. Building Research and Information, 37(5-6), 533-551, doi:10.1080/09613210903189376.

Palm, J. (2009). Placing barriers to industrial energy efficiency in a social context: A discussion of lifestyle categorisation. Energy Efficiency, 2(3), 263-270. doi:10.1007/s12053-0099042-1.

Palm, J., \& Reindl, K. (2016). Understanding energy efficiency in Swedish residential building renovation: A practice theory approach. Energy Research \& Social Science, 11, 247-255. doi:10.1016/j.erss.2015.11.006.

Palm, J., \& Thollander, P. (2010). An interdisciplinary perspective on industrial energy efficiency. Applied Energy, 87(10), 3255-3261. doi:10.1016/j.apenergy.2010.04.019. 
Persson, J., \& Grönkvist, S. (2015). Drivers for and barriers to low-energy buildings in Sweden. Journal of Cleaner Production, 109, 296-304.

Phillips, Y. (2012). Landlords versus tenants: Information asymmetry and mismatched preferences for home energy efficiency. Energy Policy, 45, 112-121. doi:10.1016/j. enpol.2012.01.067.

Sanstad, A. H., \& Howarth, R. B. (1994). 'Normal'markets, market imperfections and energy efficiency. Energy Policy, 22(10), 811-818.

Schleich, J., \& Gruber, E. (2008). Beyond case studies: barriers to energy efficiency in commerce and the services sector. Energy Economics, 30(2), 449-464. doi:10.1016/j. eneco.2006.08.004.

Serpell, A., Kort, J., \& Vera, S. (2013). Awareness, actions, drivers and barriers of sustainable construction in Chile. Technological and Economic Development of Economy, 19(2), 272-288. doi:10.3846/20294913.2013.798597.

Shove, E. (2010). Beyond the ABC: climate change policy and theories of social change. [article]. Environment and Planning A, 42(6), 1273-1285. doi:10.1068/a42282.

Sorrell, S. (2003). Making the link: climate policy and the reform of the UK construction industry. Energy Policy, 31(9), 865878. doi:10.1016/S0301-4215(02)00130-1.
Sorrell, S. (2004). The economics of energy efficiency : barriers to cost-effective investment. Cheltenham: Edward Elgar.

Sorrell, S., Schleich, J., Scott, S., O'malley, E., Trace, F., Boede, E., et al. (2000). Reducing barriers to energy efficiency in public and private organizations. Brighton: SPRU Science and Technology Policy Research.

Stern, P. C. (1992). What psychology knows about energy conservation. American Psychologist, 47(10), 1224-1232.

Swedish National Board of Housing Building and Planning, \& Swedish Energy Agency. (2013). Förslag till nationell strategi för energieffektiviserande renovering av byggnader : gemensamt uppdrag Energimyndigheten och Boverket. Eskilstuna: Energimyndigheten.

Thollander, P., \& Palm, J. (2013). Improving energy efficiency in industrial energy systems : An interdisciplinary perspective on barriers, energy audits, energy management, policies, and programs. London: Springer.

Thollander, P., Palm, J., \& Rohdin, P. (2010). Categorizing barriers to energy efficiency-an interdisciplinary perspective. In J. Palm (Ed.), Energy efficiency (pp. 49-62). Croatia: INTECH Open Access Publisher.

Weber, L. (1997). Some reflections on barriers to the efficient use of energy. [review]. Energy Policy, 25(10), 833-835. 